BNWL -791

UC -80 , Reactor

Technology

\title{
SYSTEM EFFECTIVENESS GOALS \\ FOR THE FAST FLUX TEST FACILITY
}

\author{
By \\ R. A. Harvey, S. S. Hintze, H. C. Martin, \\ M. A. McLaughlin, and 0 . B. Monteith \\ Reactor and Plant Technology Department \\ FFTF Division
}

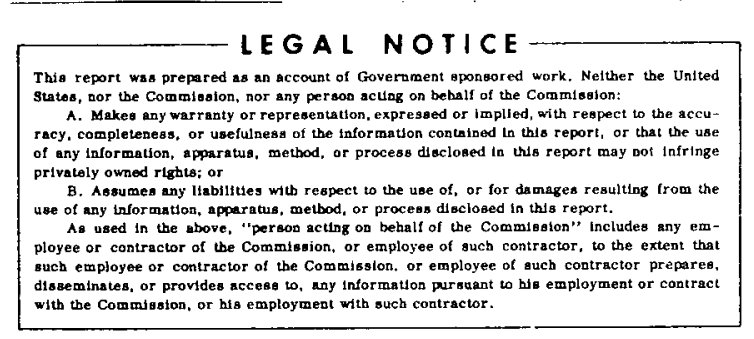

November 1969

GHET UNRESTRICTED

DISTRIBUTION MADE

DEC 15 '69

BATTELLE MEMORIAL INSTITUTE

PACIFIC NORTHWEST LABORATORIES

RICHLAND, WASHINGTON 99352

This document is 


\section{DISCLAIMER}

This report was prepared as an account of work sponsored by an agency of the United States Government. Neither the United States Government nor any agency Thereof, nor any of their employees, makes any warranty, express or implied, or assumes any legal liability or responsibility for the accuracy, completeness, or usefulness of any information, apparatus, product, or process disclosed, or represents that its use would not infringe privately owned rights. Reference herein to any specific commercial product, process, or service by trade name, trademark, manufacturer, or otherwise does not necessarily constitute or imply its endorsement, recommendation, or favoring by the United States Government or any agency thereof. The views and opinions of authors expressed herein do not necessarily state or reflect those of the United States Government or any agency thereof. 


\section{DISCLAIMER}

Portions of this document may be illegible in electronic image products. Images are produced from the best available original document. 


\title{
SYSTEM EFFECTIVENESS GOALS FOR THE FAST FLUX TEST FACILITY \\ R. A. Harvey, S. S. Hintze, H. C. Martin, M. A. McLaughlin, and 0. B. Monteith
}

\begin{abstract}
The Fast Flux Test Facility (FFTF) is an experimental facility intended for use in developing the technology for efficient electric power generation from nuclear energy. An effective design for the FFTF must allow for equipment random malfunctions in order to achieve high system availability for its intended use. This report presents system effectiveness goals and describes a reliability program aimed at achieving high plant effectiveness. The goals are intended for the guidance of subsystem designers. The reliability program indicates the types of analyses and documentation recommended by the authors.
\end{abstract}




\section{TABLE OF CONTENTS}

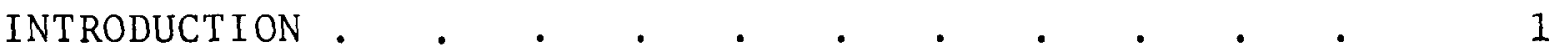

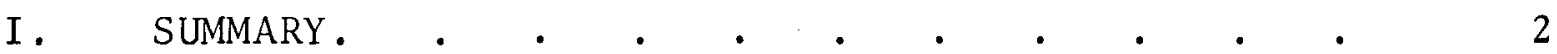

II. FFTF RELIABILITY PROGRAM $\quad$ • . . . . . . . $\quad 2$

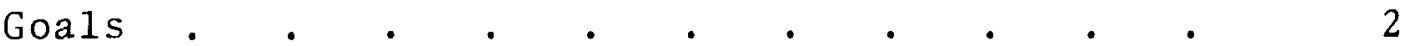

Recommended Analyses and Studies . . . . 5

Recommended Reporting Practice

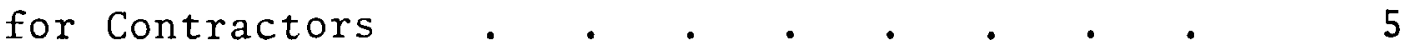

III. SYSTEMS RELIABILITY PROBLEMS • . • • • • $\quad$. 8

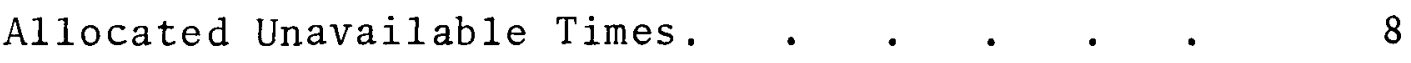

Electrical Systems . . . . . . . . . 11

Primary Electrical Power System . • • 12

Building Electrical Power System . . . 13

Structures and Utilities. . . . . . . . . 14

Structures . . . . . . . . . . . 14

Service Piping System . . . . . . . 15

Coolant Fluid Service . . . . . . . 15

Radioactive Waste System . . . . . 16

Heating and Ventilation System. . . . 16

Containment . . . . . . . . 16

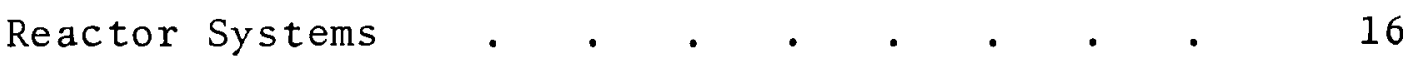

Reactor Core . . . . . . . . . . 16

Reactor Vessel and Shield . . . . . 17

Nuclear Control System. . . . . . . 17

First Core Fuel Assembly . . . . . . 17

Component Handling Systems .

Reactor Refueling System . . . . . 18

Nonirradiated Fuel Handling System. • • 18

Irradiated Fuel Hand1ing System . . . 18

Radioactive Maintenance System. . . . 18

Heat Transport System . . . . . . . 18 
BNWL - 791

Irradiation Test Systems . . . . . . . 19

Closed Loop System • $\cdot$.

Short-Term Irradiation Facility . . . . 20

Auxiliary Systems . . . . . . . . 20

Sodium Receiving and Processing System . . 20

Inert Gas Receiving and Processing

System . . . . . . . . . . 20

Decontamination and Cleaning System . . . 21

Instrumentation, Control, and Data

Handling Systems . . . . . . . . . 21

Control and Data Handling . . . . . . 21

Reactor and Vessel Instrumentation System . 21

Plant Instrumentation System. . . . . 22

Fue1 Failure Monitoring System . . . . 23

F1ux Monitoring and Control System . . . 23

Radiation Monitoring System. . . . . 23

Nuclear Plant Protection System . . . . 23

Inert Gas Cell Examination Facility . . . . 24

REFERENCES • • • • • • • • • • • • • 25 
BNWL - 791

\section{SYSTEM EFFECTIVENESS GOALS \\ FOR THE FAST FLUX TEST FACILITY}

\section{INTRODUCTION}

This report describes work performed by Battelle-Northwest under Contract (AT)-1830 for the Division of Reactor Development, U.S. Atomic Energy Commission.

This work covered the establishment of effectiveness goals for the FFTF Systems and the definition of areas where improvement over the state-of-the-art will be required to meet the goals. In most cases, a system goal is expressed as the maximum permissible reactor unavailability attributable to the system. "Availability" is defined as "the probability that the system is operating at any point in time when used under stated conditions." It is usually expressed as either a percentage of total time or as a number of hours in a given length of time. The term "effectiveness" is defined as "the probability that the system will accomplish an assigned mission successfully whenever required." 


\author{
SYSTEM EFFECTIVENESS GOALS \\ FOR THE FAST FLUX TEST FACILITY \\ I. SUMMARY
}

Based on the goal of $75 \%$ reactor availability (full power operation) for the FFTF(1) and allowing $15 \%$ unavailability as a result of refueling and scheduled maintenance, a comparison was made between the resultant goal of 877 hours per year allotted for equipment failures and the current state-of-the-art. ${ }^{*}$ As shown by Table 1, the current state-of-the-art is expected to result in about 3800 hours outage time per year for equipment failures. Hence, installations of state-of-the-art equipment would provide an FFTF availability of only about $42 \%$ (43\% lost time for equipment failures and $15 \%$ lost time for fue 1 charging and scheduled maintenance).

To provide maximum availability for FFTF, it is recommended that:

Heavy emphasis be placed on improving the state-of-the-art, particularly in the heat transport, control and instrumentation, irradiation test systems, and component handling systems.

Contractors be required to conduct extensive reliability programs and analyses as described herein.

\title{
II. FFTF RELIABILITY PROGRAM
}

$\underline{\text { GOALS }}$

The reliability program was initiated for the purposes of improving the effectiveness of the FFTF design by encouraging early recognition of the effects of random failures and maintaining the effectiveness of the FFTF design by monitoring the reliability (and its effect on plant availability) through the design, fabrication, installation, and initial operating stages. Figure 1 presents a schematic representation of the program

* State-of-the-art estimates in this report are generally based on the subjective judgements of $B N W$ design engineers. 
showing the reliability analysis relationships between BNW and its contractors throughout all stages of the FFTF Project. It can be seen from the schematic that the program depends on the formation of goals to meet the needed functions and requirements. It also depends on subsequent predictions and estimations which permit comparison with the goals. Analyses of reliabilities and availabilities for a system will not in themselves guarantee a satisfactory reliability and availability. The designer must use the results of the analyses as an integral part of the design process. Reliability predictions can indicate weak spots in the design by identifying sources and causes of unreliability. Such predictions are used in making design decisions on the selection of a concept and on the amount of redundancy required in order to meet a goal.

TABLE 1. Comparison of Effectiveness Goals and State-of-the-Art

Electrical Systems

Structures and Utilities

Reactor Systems

Component Handling Systems

Heat Transport System

Irradiation Test Systems

Auxiliary Systems

Control and Instrumentation Systems

Inert Gas Exam Facility
Unavailability Hrs/yr.

State of $\frac{\text { the Art }}{2} \quad \frac{\text { Goal }}{2}$

4

4

140

140

350

174

2100

193

368

193

45

45

760

125

0 


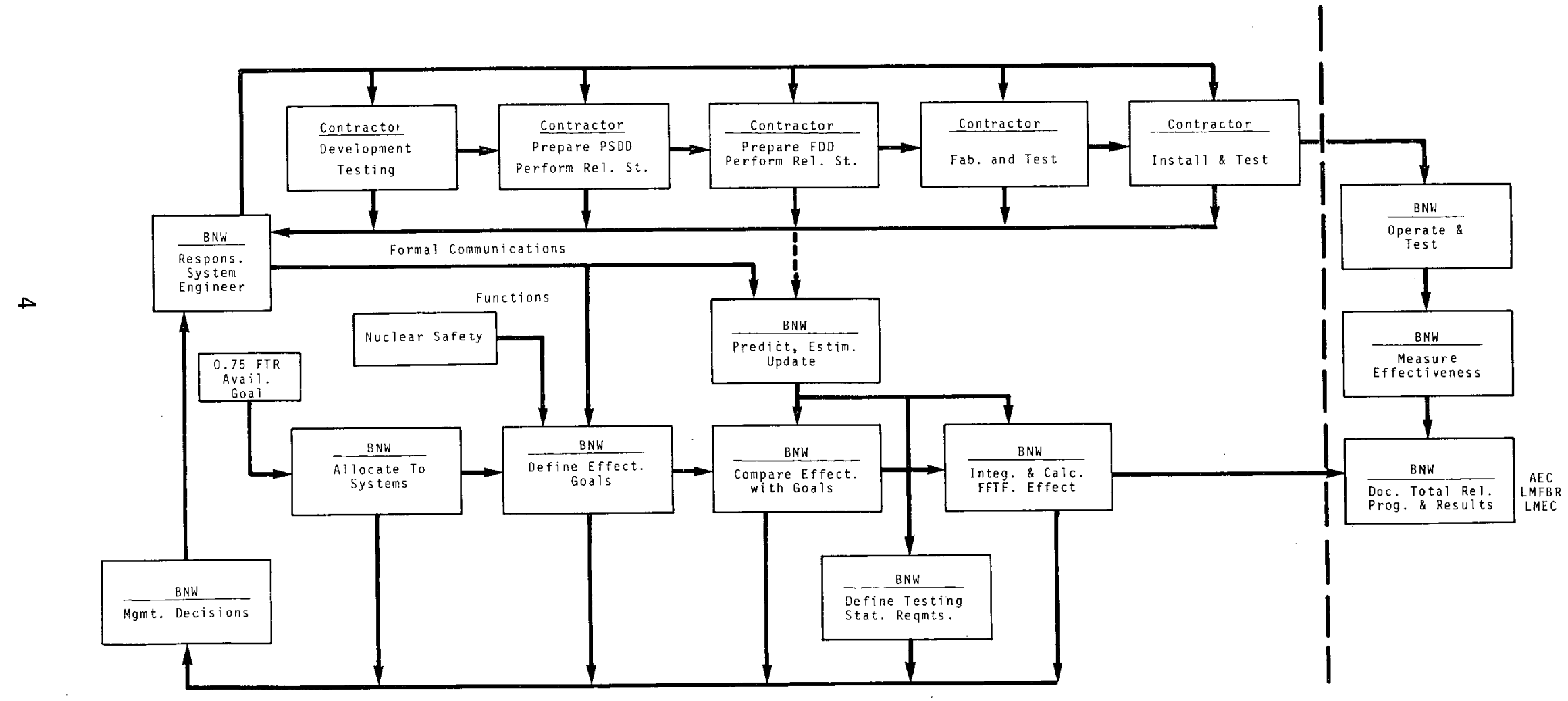

FIGURE 1. Schematic Representation of Reliability Analysis Steps Relating to FFTF Design, Fabrication, and operation 
The goals considered in this document relate to losses in FFTF effectiveness caused by random malfunctions that occur after the system has been "debugged." The debugging process is expected to eliminate the malfunctions that result from design deficiencies. On the other hand, the reliability analysis will indicate the weak spots in the design. Changes in design will generally change the reliability of the system. Therefore, it is anticipated that the goals will be revised after the first systems analysis has been completed. The justifications used to arrive at goals for any particular system include the FTR unavailability allocation and safety. These goals should be interpreted as design objectives, rather than being considered as firm requirements.

\section{RECOMMENDED ANALYSES AND STUDIES}

To ensure the maximum probability of meeting the overall FFTF goal of $75 \%$ availability, the authors recommend that a number of failure mode and effects analyses (FMEA) reliability analyses and predictions (RAP) and safety reliability analyses (SRA) be made as 1 isted in $\mathrm{Tab} 1 \mathrm{e} 2$. These recommendations will. be applicable to FFTF contractors when included in work packages and work plans.

\section{RECOMMENDED REPORTING PRACTICE FOR CONTRACTORS (4)}

The authors recommend that:

- The contractor include in his reliability analysis program the systems for which he has systems engineering responsibility.

- The contractor provide a reliability analysis program plan report which clearly describes:

- The contractor's understanding and interpretation of the goals for each of the pertinent systems with a description of the engineering approaches contemplated. 


\section{TABLE 2. Summary of Recommended Analyses}

\section{System}

- Primary Electrical Power

- Building Electrical Power

- Structures

- Service Piping

- Radioactive Waste

- Heating and Ventilating

- Reactor Containment

- Reactor Core

- Reactor Vessel and Shield

- Reactor Nuclear Control Components

- First Core Fue1 Assemb1y

- Reactor Refueling

- Nonirradiated Fuel Handling

- Irradiated Fue 1 Handling

- Radioactive Maintenance

- Reactor Heat Transport

- Closed Loops

- Short-Term Irradiation Facility

- Sodium Receiving and Processing

- Inert Gas Receiving and Processing

- Decontamination and Cleaning

- Central Control and Data Handling

- Reactor and Vesse1 Instrumentation

- Plant Instrumentation

- Fuel Failure Monitoring

- Flux Monitoring and Control

- Radiation Monitoring

- Nuclear Plant Protection

- Inert Gas Cell Examination Facility

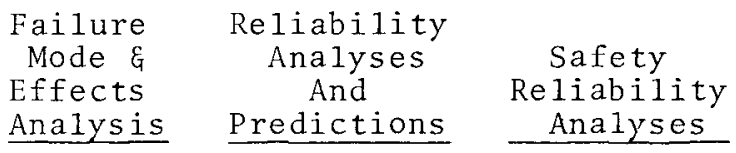

$\mathrm{X}$

$\mathrm{X}$

$X^{(a)}$

$\mathrm{X}$

$\mathrm{x}$

$x$

$\mathrm{x}$

$\mathrm{x}$

$\mathrm{X}$

$\mathrm{X}$

$\mathrm{X}$

$x$ $x^{(b)}$

$\mathrm{X}(\mathrm{b})$

$\mathrm{X}$

$x$ (b)

$x^{(b)}$

(a) This analysis wizl include alz penetrations and alz containment functions.

(b) Safety analyses of subsystems that are a part of or that provide input to the Protection system are to be included under the Nuclear Plant Protection System

(c) An availability analysis of the system for each major function is recommended 
- The reliability program and monitoring procedures to be used throughout the contract period.

- Progressive reliability milestones and monitoring schedule.

- The contractor provide periodic reports which include, for the Reliability Program:

- Status of design reviews and pertinent results.

- Tradeoffs and reliability considerations in the selection of components and configurations.

- Reliability and availability allocations and requirements included in subcontractor or vendor-supplied items.

- Reliability and availability predictions

- Summary of test results.

- Summary of reliability problem areas and planned solutions.

- Adherence to reliability program schedule.

- Analysis of the effect that schedule changes, design problems, and procurement delays will have upon the Reliability Program.

- Status of Reliability Program activities in relation to the program plan submitted in the initial report.

- The contractor provide separate reliability analysis and prediction reports which include:

- Reliability predictions.

- Prediction of reactor'unavailability attributable to the system.

- Comparison of current design reliability status of the equipment with the goals.

- Analysis of failure modes, summary of findings, and plan for design changes.

- Results of tolerance, stability, and life tests. 
- The effects of total program problems upon reliability status and achievements.

- Actions, if required, that are planned in order to improve the reliability of the design.

These recommendations will be applicable to FFTF contractors when included in approved work packages and work plans.

\section{SYSTEMS RELIABILITY PROBLEMS}

\section{ALLOCATED UNAVAILABLE TIMES}

The FTR is considered available when it is capable of operating at full power. (5) Assuming that refueling requires $15 \%$ of the time, only $10 \%$ remains for those equipment malfunctions which cause reactor unavailability. The unavailable times allocated to the various systems were scaled to fit approximately into the $10 \%$ of the time that remains for equipment malfunctions. As a simplification, overlapping downtimes from more than one cause were not considered. These allocated goals for system unavailabilities are generally independent of the detailed hardware configurations. An allocated unavailability is considered to be the maximum permissible reactor unavailability chargeable to the pertinent system. (See Figure 2 and Table 3). It is not intended that normal design be degraded or relaxed if the associated reactor unavailability is less than the maximum permissible. 


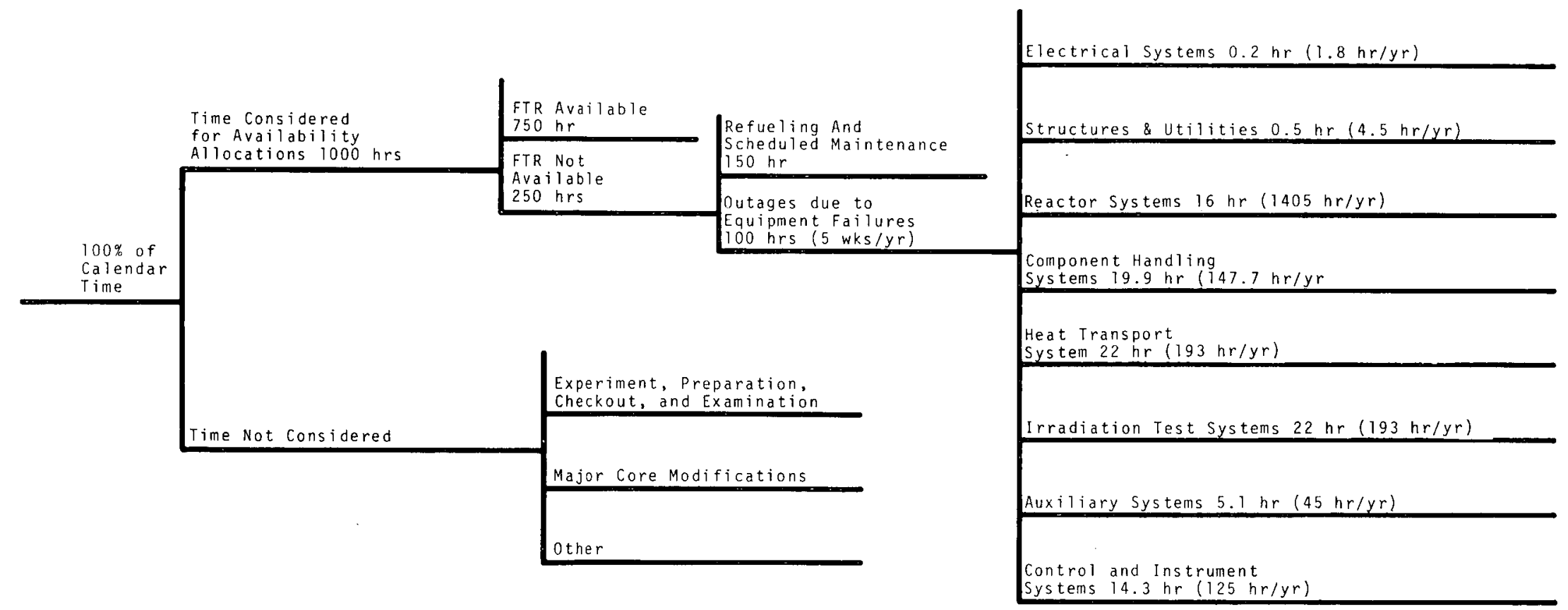

FIGURE 2. Unavaizabizity Time Alzocations (Numbers are Based on a $1000 \mathrm{hr}$. Reference Time) 
BNWL - 791

TABLE 3. Reactor Unavaizabizities

Systems

Electrica1 Systems

- Primary Electrical Power System

- Building Electrical Power System

- Communications System

- Iighting System

Structures and Utilities

- Structures

- Site Facilities

- Service Piping System

- Radioactive Waste System

- Heating and Ventilation System

- Plant Fire Protection System

- Reactor Containment System

Reactor Systems

- Reactor Core Component

- Reactor Vessel and Shield Component

- Reactor Nuclear Control Components

- First Core Fuel Assembiy

Component Handling Systems

- Reactor Refueling System

- Nonirradiated Fuel Handling System

- Irradiated Fue1 Handling System

- Radioactive Maintenance System

Heat Transport Systems

- Reactor Heat Transport System

Irradiation Test Facilities

- Closed Loop Test Systems

- Short Term Irradiation Facility
Hours Unavailable-FTR

Allocations

$\begin{array}{cl}\mathrm{Hr} / 1000 \mathrm{hr} & \mathrm{Hr} / \mathrm{yr} \\ 0.1 & 0.9 \\ 0.1 & 0.9 \\ 0 & 0 \\ 0 & 0\end{array}$

0.1

0.9

0

0

$0.1 \quad 0.9$

0

0

$0 \cdot 1$

0.2

0.9

0

1.8

10

$0 *$

$1 *$

87.7

0

9

43.8

14.7

0.1

128.9

0.1

5.0

0.9

0.9

44
175

18

* Analyses are required because of safety. 
BNWL - 791

\section{TABLE 3. Reactor Unavailabilities (contd)}

\section{Systems}

Auxiliary Systems

- Sodium Receiving and Processing System

- Inert Gas Receiving and Processing System

- Auxiliary Heating and Cooling System

- Decontamination and Cleaning System

- Chemical Analysis Facility

Instrumentation and Control Systems

- Central Control and Data Handling System

- Reactor and Vessel Instrumentation System

- Plant Instrumentation Systems

- Fuel Failure Monitoring System

- Flux Monitoring and Control System

- Radiation Monitoring System

- Nuclear Plant Protection System

Inert Gas Ce11 Examination Facility

Tota 1
Hours Unavailable-FTR

Allocations

Hr/1000 hr $\quad$ Hr/yr

4

35

1

9

0

0.1

0

0

0.9

0
0.5

4.4

6.0

3.0

1.5

2. 5

0.5

0.3

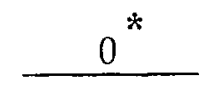

100.0
52.6

26

13

22

4.4

2.6

0

877.4

* Analysis is required for test information effectiveness.

\section{ELECTRICAL SYSTEMS}

The electrical systems group consists of four systems. Primary electrical power will be received from the Bonneville Power Administration (BPA) power grid by the primary power system, transmitted to the FFTF substation, and delivered to the FFTF building electrical power system. The building electrical power system delivers electrical power, including emergency electrical power, to all other FFTF systems, as required. 
The lighting and communications systems technologies are well established and high reliabilities are attainable by standard practices. No analyses are required for the lighting and communications systems.

Failures in the BPA grid, the primary electrical power system, and the building electrical power system can affect the entire FFTF operations.

$\underline{\text { primary Electrical Power System }}{ }^{(6)}$

There are two types of outages associated with the electrical utility systems. The sustained outage (more than $1 / 2 \mathrm{sec}$ duration) causing complete or partial loss of power can be backed up by emergency power generation facilities. The second outage type is a momentary disturbance lasting less than $1 / 2$ sec and is the result of surges on the system. These surges can be caused by lightning strikes on or near the transmission lines, switching surges on the system, or insulation flashovers of various causes. While the outages with a duration of $1 / 2 \mathrm{sec}$ or less cause no concern to normal industrial loading, existing Hanford production reactors have experienced false scrams as a result of thesurges.

The planned operation of the primary electrical power system is to divide the FFTF loads between the two $115 / 13.8 \mathrm{kV}$ transformers and to maintain this division of loads via trans mission 1 ines to the BPA network. Should one transmission line fail, the system allows both transformers to be manually switched to the other transmission line. This would still provide full power to the FFTF. In like manner, should one transformer fail, the FFTF loads can be manually switched to the other transformer secondary, thus providing at least $75 \%$ full power with one failed transformer. Initially, failure of one primary supply will cause a controlled shutdown; however, the reactor may be restarted and operated on the remaining primary 
supply, providing the emergency system is operating and is connected to the pump pony motors. A scram would result if the remaining primary supply failed. (7)

Sustained outages resulting from primary electrical power system equipment failures will cause the reactor to shut down. Momentary outages resulting from lightning, and other outages may or may not cause the reactor safety circuits to trip. A maximum unavailability of the reactor resulting from primary electrical power system malfunction and momentary outages is allocated as $0.10 \mathrm{hr} / 1000 \mathrm{hr}$ operation. Since this is based on past history, standard technology is sufficient to meet the availability goal.

The minimum time to restore the reactor to power following a controlled shutdown is $4 \mathrm{hr}$. (8) This would be the restoration time using emergency power. The expected number of failures of the primary electrical power system is then one in $40,000 \mathrm{hr}$, or the $\mathrm{MTBF}$ is $40,000 \mathrm{hr}$. Thus, the required reliability for an assumed 9 -week period is:

$$
\begin{aligned}
\mathrm{R}= & \mathrm{e} \frac{-t}{\mathrm{MTBF}}=\mathrm{e} \frac{-1512}{40,000}=0.9629 \\
= & \text { Probability of operating the primary electrical power } \\
& \text { system without failure during an assumed } 9 \text {-week FTR } \\
& \text { operating cycle. }
\end{aligned}
$$

Building Electrical Power System ${ }^{(9)}$

The building electrical power system provides equipment, circuits, and systems to receive the primary power. It transforms the voltage to the level required by the various FFTF loads and distributes the power via safe, protected and reliable circuitry. The system receives the primary power at $13.8 \mathrm{kV}$ and distributes it at: $2400 \mathrm{~V}, 480 \mathrm{~V}$, and 1 ower; and 125 and $24 \mathrm{Vdc}$. All the voltage level distributions are redundant, to the extent that no single insulation or equipment failure can cause the 
complete loss of a necessary reactor or building power source. A requirement exists $(10)$ for the referenced concept that two sources of primary power must be available to supply major loads. Therefore, building power cannot be lost from a single electrical power failure. The system provides both ac and dc standby power for emergency operation of the FFTF in the event that the primary power source should fail.

The predicted unavailability of the reactor due to failures of the emergency power system is so small it may be neglected. In order to provide the required safety, the emergency power backup for each bus must be designed for a reliability of 0.999 and an availability of 0.999 .

A failure in the $2.4 \mathrm{kV}$ "system would have the same effect as a primary electrical power system failure. Therefore, the same goal has been established: $0.1 \mathrm{hr} / 1000 \mathrm{hr}$ unavailability. This means the required reliability of the $2.4 \mathrm{kV}$ system for an assumed 9-week FTR operating cycle must be 0.96 .

\section{STRUCTURES AND UTILITIES}

\section{Structures}

Most of the structures facility will be passive. Once constructed, its only task is to remain in that static condition. All structures provided by the system are we 11 within the state-of-the-art and are not generally prone to random failure. However, the system might provide equipment upon which the continued operation of the facility could depend. For example, the high bay bridge crane transfers nonirradiated fuel from the railroad cars to the nonirradiated fuel handling area. Other bridge cranes in the irradiated fuel handling, radioactive maintenance, fuel examination areas and other equipment may aiso fall into this category.

The goal for maximum reactor unavailability allocated to the structures facility has been set at $0.1 \mathrm{hr} / 1000 \mathrm{hr}$. At this 
time, we believe standard technology is sufficient to ensure that the reactor unavailability chargeable to this system will not exceed the goal.

Service Piping System

The service piping system includes several piping services whose interruption could interrupt facility operation. Compressed air is required by critical instrumentation and perhaps containment valving. Process water is required for air compressor and aftercooler cooling. Makeup water for the storage basins is supplied by the demineralized water service that is supplied by the process water service. The process sewers dispose of the air compressor cooling effluent. Cooling fluid removes heat from the cold traps of the sodium processing system, the storage basin of the irradiated fuel handling system, the inert gas atmospheres, and the air-conditioned room atmospheres.

The greatest calamity that could beset the compressed air service would be the plugging or bursting of the critical branch line. External damage to a branch line would normally be considered failure of another system and simultaneous failure of two valves would be fairly remote.

Coolant Fluid Service

There are three coolant fluids supplied by this service: low-temperature coolant (refrigerated), which cools atmospheres and the secondary sodium pumps; medium temperature coolant $\left(90^{\circ} \mathrm{F}\right)$, which cools the reactor cavity, sodium storage cells, closed-1oop ce11s, etc.; and high-temperature coolant (150 to $200^{\circ} \mathrm{F}$ ), which cools decay storage, cold traps, etc. These services are considered to have very high availabilities.

The goal for reactor unavailability chargeable to the Service Piping System is $0.1 \mathrm{hr} / 1000 \mathrm{hr}$. This divides into a ratio of about 1 to 5 between the compressed air and the cooling fluid services.*

* Estimate based on use and system complexities. 
BNWL - 791

$\underline{\text { Radioactive Waste System }}$

The reactor does not require the radioactive waste system for continued operation.

Heating and Ventilation System

Sufficient redundancy should be included in the cooling capability so that all of the calculated cooling capacity for the containment zones must be available before the operation is considered safe. Another area of concern involves admission of air into an inert gas atmosphere. Areas having inert gas atmospheres are equipped with air inlets and exhausts for use during maintenance periods. Either air leaks or accidental opening of an air inlet could cause purging of the inert gas area and subsequent loss of the required negative pressure. This would result in an air atmosphere which must be considered dangerous where inert gas is required for operation.

In order for the heating and ventilation system to comply with the overall FFTF goal of $75 \%$ availability, the heating and ventilation system unavailability shall not exceed $0.1 \mathrm{hr} / 1000 \mathrm{hr}$ as a result of malfunctions. This goal can probably be accomplished using standard technology.

Containment

The reactor unavailability goal allocated to the reactor containment system is $0.2 \mathrm{hr} / 1000 \mathrm{hr}$ maximum. Reactor unavailability might result from prolonging an existing outage as a result of the crane malfunction. Safety requirements and recovery procedures might also cause reactor unavailability in the event that a penetration seal is found to leak. Stateof-the-art technology should adequately satisfy this goal. REACTOR SYSTEMS

Reactor Core

In order to achieve the $75 \%$ availability goal, the reactor core must not cause more than 10 -hr unavailability per 
1000 calendar hr. Improvements beyond the present state-of-theart will probably be required to satisfy this goal; however, it is difficult to estimate the order of improvement required.

Reactor Vessel and Shield

In order to be effective, the reactor vessel and shield component must be intact $100 \%$ of the time and must not leak, crack, or develop excessive corrosion. The reactor unavailability allocated to the reactor vesse 1 and shield component is zero. The system is expected to function without failure during the lifetime of the reactor.

Nuclear Control System

In order to meet the $75 \%$ availability goal, the nuclear control system must exhibit an unavailability not greater than $1 \mathrm{hr} / 1000 \mathrm{hr}$. For a first approximation, we can assume that $60 \%$ of all control system failures result in FTR shutdown, and the rest may be repaired during refueling at no penalty. The goal for mean-time-to-repair is $75 \mathrm{hr}$. The required reliability goal for all nuclear devices would be 0.978 . If there are 24 such devices and their reliabilities are equal, each must display a 0.999 reliability. An improvement in the state-of-the-art is required to attain this goal; however, no estimate of the degree of improvement required can yet be made.

First Core Fuel Assembly

In order to achieve the $75 \%$ availability goal, the fuel must exhibit an unavailability not greater than $5 \mathrm{hr} / 1000 \mathrm{hr}$. The mean-time-to-repair (MTR) goal is shortened from 5 or 6 days to $100 \mathrm{hr}$. The necessary reliability for all fuel is 0.951 . Improvements beyond the present state-of-the-art will probably be required to satisfy this goal. 


\section{COMPONENT HANDLING SYSTEMS}

Failure of any of the systems in this group can, at the most, delay reactor startup subsequent to an outage. None of these systems interferes with the reactor during operation. Reactor Refueling System

In order to support the $75 \%$ availability goal, the reactor unavailability goal due to the reactor refueling system is $14.7 \mathrm{hr} / 1000$ calendar $\mathrm{hr}$. It is difficult to estimate the present state-of-the-art for this system, but present technology should be adequate to meet this goal.

Nonirradiated Fue1 Hand1ing System

The equipment involved is well within the state-of-theart. Therefore, the allotted goal for the FTR unavailability due to malfunctions in the nonirradiated fuel handiing system is $0.1 \mathrm{hr} / 1000 \mathrm{hr}$.

Irradiated Fue 1 Hand1ing System

The goal set for the irradiated fuel handling system is that the reactor unavailability due to the irradiated fue 1 handling system should be no more than $0.1 \mathrm{hr} / 1000$ calendar hr. State-of-the-art technology should be adequate to attain this goal.

Radioactive Maintenance System

A maximum reactor unavailability of $5 \mathrm{hr} / 1000$ calendar $\mathrm{hr}$ attributable to the radioactive maintenance system is the system goal. A state-of-the-art number of $25 \mathrm{hr} / 1000 \mathrm{hr}$ is estimated. HEAT TRANSPORT SYSTEM

In order to meet the overall FFTF availability goal of $75 \%$, a maximum of $22 \mathrm{hr}$ of reactor downtime per $1000 \mathrm{hr}$ total time was allotted to reactor heat transport system failures. Preliminary reliability and availability analyses were performed (11) for systems with various numbers of coolant loops. 
The nonredundant case of three loops shows the state-of-the-art availability to be $240 \mathrm{hr} / 1000 \mathrm{hr}$. An eleven-fold availability increase is necessary.

In order to upgrade the system availability, it will be necessary for the designer to:

- Make an initial assessment of the reliability and availability.

- Develop a plan for upgrading the system availability to meet the specified availability goal of $97.8 \%$.

- Assess the effect of any design changes on system reliability and availability.

- Using tradeoff studies of other means, substantiate the reason for any design choices which downgrade system reliability and availability.

\section{IRRADIATION TEST SYSTEMS}

\section{Closed Loop System}

Coolant flow must be maintained in the closed loop test channels during reactor operations and after shutdown to remove heat from test specimens. Therefore, redundant pumps are recommended. The pumps and the associated checkvalves seem to be the most critical components. If all pumps fail simultaneously, the reactor will be shut down with the emergency pump providing decay cooling. The associated checkvalves have two failure modes: open and closed. If a checkvalve fails open, recirculation through the redundant lines will cause the reactor to be shut down. We assume that if the checkvalve failed open, the fault could be detected and the reactor shut down.

The operating time, duty cycles, and complexity of the various tests to be performed in the closed test loops are expected to vary considerably. Past experience with testing has shown that the tests in general will run from 6 months to $2 \mathrm{yr}$. There will probably be more than one closed loop. The previously mentioned problems causing any of the closed loops to function 
improperly could cause the reactor to shut down. Therefore, as the number of closed loops increases, the availability of the reactor will decrease.

The state-of-the-ajt FTR unavailability due to the closedloop test system is estimated as $40 \mathrm{hr} / 1000 \mathrm{hr}$. This estimate is based on test loops with no redundancies.

In order to meet the overall FFTF availability goal of $75 \%$, a maximum of $20 \mathrm{hr} / 1000 \mathrm{hr}$ reactor unavailability is allocated to the closed loop system. If the concept calls for five, active closed test loops, then the reactor unavailability allocated to each test loop is $4 \mathrm{hr} / 1000 \mathrm{hr}$. The function will be assumed to be performed if adequate heat removal capacity is available and safety is not jeopardized.

Short-Term Irradiation Facility

In order to meet the reactor availability goal of $75 \%$, a goal of $2 \mathrm{hr} / 1000 \mathrm{hr}$ maximum of reactor unavailability is allocated to the short-term irradiation facility. For a reactor downtime goal of $75 \mathrm{hr}$ for each malfunction in the system that causes reactor unavailability, the mean time between those failures that cause reactor unavailability should be not less than about 6 years. This corresponds to a 1000-hr reliability of approximately 0.97. Improvements beyond the present state-of-the-art will probably be required to satisfy this goal. AUXILIARY SYSTEMS

Sodium Receiving and Processing System

In order to meet the $75 \%$ reactor availability goal, an unavailability of $4 \mathrm{hr} / 1000 \mathrm{hr}$ was allocated to the sodium receiving and processing system. This goal should not require improvement in the state-of-the-art.

Inert Gas Receiving and Processing System

The inert gas receiving and processing system is not considered critical with respect to the reactor availability. 
A failure of this system* will not cause the reactor to shut down immediately. However, a prolonged failure may cause reactor unavailability. In order to meet the reactor availability goal of $75 \%$, an unavailability of $1 \mathrm{hr} / 1000 \mathrm{hr}$ was allocated to the inert gas receiving and processing system. This goal should not require improvement in the state-of-the-art.

Decontamination and Cleaning system

We estimate failures in the decontamination and cleaning system will not extend reactor outages by more than $0.1 \mathrm{hr} / 1000 \mathrm{hr}$. Standard technology should suffice to attain this goal. INSTRUMENTATION, CONTROL, AND DATA HANDLING SYSTEMS Control and Data Handling

Each of the many functions of the central control and data handling system (CCDH) will have a different effect upon reactor availability. Thus, the effect of the data display function is different from the effect of the heat transport control function, though both functions may require the computers and items of peripheral equipment. A goal for maximum unavailability of the FFTF reactor as a result of $\mathrm{CCDH}$ equipment failures is established as $0.5 \mathrm{hr} / 1000 \mathrm{hr}$. The state-of-the-art is sufficiently advanced to attain this goal.

Reactor and Vessel Instrumentation System

A11 of the instrument sensors are exposed to the hostile environment of elevated temperature, high gamma and neutron fluxes, mechanical vibration and thermal shock within the reactor vessel. Because the combined effect and severity of these conditions produce an environment that has not been previously experienced, each of the sensors of reactor instrumentation are

* Cover gas pressure controlzer malfunctions are considered as malfunctions of another system. 
in the developmental category. In addition to the needed development of sensors for the operational environment, there exist also the problems of providing:

- Suitable wiring and cable from the sensor to the outside of the vessel.

- Suitable connectors.

- Maintenance equipment and handling machinery.

- Functional testing of the installed sensors.

Other problems associated with the sensors of reactor instrumentation concern: the signal-to-noise ratio that may result from a neutronic environment; the changes in output with respect to accuracy, sensitivity, and drift as a result of the environment; and the possibility of abnormal failure modes.

The state-of-the-art reactor unavailability of $60 \mathrm{hr}$ per $1000 \mathrm{hr}$ is main $1 \mathrm{y}$ caused by the in-channel instrumentation. This allocation is based on the assumptions of no in-channel instrumentation redundancy and a thermocouple failure rate of 0.1 failures/yr per thermocouple. We also assume that flowmeter malfunctions do not require the reactor to shut down.

\section{P1ant Instrumentation System}

The plant instrumentation system will be failsafe in design; i.e., a device or system shall fail in the safe condition for that device or system, or the device or system shall fail in position in its last condition. The state-of-the-art reactor unavailability is estimated to be $15 \mathrm{hr} / 1000 \mathrm{hr}$. Approximately $80 \%$ of the unavailability is expected to be attributable to spurious scrams caused by instruments in this system which supply inputs to the nuclear plant protection system. The goal for reactor unavailability chargeable to the plant instrumentation system is $3 \mathrm{hr} / 1000 \mathrm{hr}$. Thus, in order to achieve allocated availability a five-to-one improvement is necessary. 
BNWL - 791

Fuel Failure Monitoring System

The planning of operations for the fuel failure monitoring system is in preparation and not fully defined. It can be expected that an indication of fission products might give rise to a decision to initiate reactor shutdown. However, present plans do not include automatic reactor shutdown. The decision to initiate shutdown will result from analysis and interpretation of results and correlation with other data. The reactor unavailability chargeable to the fuel failure monitoring system is $1.5 \mathrm{hr} / 1000 \mathrm{hr}$.

Flux Monitoring and Control System

The reactor unavalability allocated to the flux monitoring and control system is $2.5 \mathrm{hr} / 1000 \mathrm{hr}$. Approximately half the unavailability chargeable to this system is expected to be attributable to spurious scrams caused by instruments in this system which supply inputs to the nuclear plant protection system. Estimated state-of-the-art unavailability for this system is $10 \mathrm{hr}$.

\section{Radiation Monitoring System}

Assuming $4 \mathrm{hr}$ reactor downtime for each system malfunction, the unavailability allotment of $0.5 \mathrm{hr} / 1000 \mathrm{hr}$ requires that the mean-time-between-failures be not less than about 1 yr for the critical parts of the system. This corresponds to a reliability of about 0.9 for a $1000-h r$ period.

Nuclear plant Protection System

Since this system is a minor contributor, in terms of unavailability, little improvement can be expected. A goal of $0.3 \mathrm{hr} / 1000 \mathrm{hr}$ is established as a reasonable reactor unavailability allocation chargeable to the plant protection system. Standard technology should be adequate to attain this goal. 
BNWL- 791

\section{INERT GAS CELL EXAMINATION FACILITY}

The primary function of the inert gas cell examination facility is to permit retrieval of the test information. While the facility does not essentially affect the testing irradiation effectiveness, it has a high effect on the test information effectiveness.

The facility must be available for use at least $70 \%$ of the time. The facility may be required to perform "limited interim examinations" during a single reactor outage.

In the event of a failure which could delay returning the component to the reactor, the restart would not normally be delayed, especially if a replacement were available. Consequently, there would be no reactor unavailability attributable to the facility. However, the availability of the equipment necessary for limited interim examination must be at least $90 \%$ in order to minimize the inconveniences to the individual experimenters. 
BNWL - 791

\section{REFERENCES}

1. M. Shaw. Unpublished Data. U.S. Atomic Energy Commission, Washington, D.C., January 23, 1966. (Memorandum to D. G. Williams: East Flux Test Facility-Program Direction)

2. Design and Development Quality Assurance Requirements for the FFTF, BNWL-510. Battelie-Northwest, Richland, Washington, october $23,1968$.

3. Eabrication, Construction, and Installation Quality Assurance Requirements for the FFTF, BNWL-511. Battelie-Northwest, Richland, Washington, March 15, 1968.

4. Handbook - Reliability Engineering, NAVWEPS-00-65-502. Naval ordnance Laboratory, White oak, Maryland.

5. E. E. Kintner. Unpublished Data. Battelle-Northwest, Richland, Washington, December 9, 1968. (Letter to Manager, Richland operations office: Transmittal of Conference Report; FETF Reliabizity and Avaizability)

6. 0. B. Monteith. Preliminary Reliability Analysis of the Primary Electrical Power System, System 11, BNW-691. Batteile-Northwest, Richland, Washington, February 1968.

7. W. B. McDonald. Unpublished Data. Battelle-Northwest, Richland, Washington. (Letter to J. M. McCambell (Bechtel): Bechtel Baseline Review of CSDD No. 11 as Reported in BCL-6?)

8. Unpublished Data. BattelZe-Northwest, Richland, Washington. [Personal Communication with $J$. E. Mills (BNW/EFTF)]

9. 0. B. Monteith. Preliminary Reliability Prediction for the FFTE Conceptual Building Electrical Power System, System 12 , BNWL-813. Battelle-Northwest, Richland, Washington, August 1968.

10. Conceptual Design Description for the System, BNWL-500, Volumes 11 through 91. Battelie-Northwest, Richland, Washington.

11. R. A. Harvey, H. G. Johnson, M. A. McLaughlin, and E. F. Witeck. Technical Basis for Main Heat Transport System Concept and Concept Configuration Selection, BNWL-554, Battelle-Northwest, Richland, Washington, September 1967. 


\section{DISTRIBUTION}

No. of

Copies

\section{OFFSITE}

AEC Chicago Patent Group

G. H. Lee

AEC Division of Reactor Development and Technology

M. Shaw, Director, RDT

Asst Dir for Nuclear Safety

Analysis \& Evaluation Br, RDT:NS

Environmental \& Sanitary Engrg Br, RDT:NS

Research \& Development Br, RDT:NS

Asst Dir for Plant Engrg, RDT

Facilities $\mathrm{Br}$, RDT:PE

Components $\mathrm{Br}$, RDT:PE

Instrumentation \& Control $\mathrm{Br}, \mathrm{RDT}: \mathrm{PE}$

Liquid Metal Systems $\mathrm{Br}$, RDT:PE

Asst Dir for Program Analys is, RDT

Asst Dir for Project Mgmt, RDT

Liquid Metals Projects Br, RDT:PM

FFTF Project Manager, RDT:PM

Asst Dir for Reactor Engrg, RDT

Control Mechanisms $\mathrm{Br}$, RDT:RE

Core Design $\mathrm{Br}$, RDT:RE

Fuel Engineering $\mathrm{Br}, \mathrm{RDT}: \mathrm{RE}$

Fuel Handling $\mathrm{Br}$, RDT: RE

Reactor Vessels Br, RDT:RE

Asst Dir for Reactor Tech, RDT

Coolant Chemistry $\mathrm{Br}$, RDT:RT

Fuel Recycle $\mathrm{Br}$, RDT:RT

Fuels \& Materials $\mathrm{Br}$, RDT:RT

Reactor Physics Br, RDT:RE

Special Technology $\mathrm{Br}$, RDT: RT

Asst Dir for Engrg Standards, RDT

EBR-II Project Manager, RDT:PM

207 AEC Division of Technical Information Extension

1 AEC Idaho Operations Office

Nuclear Technology Division

C. W. Bills, Director

1 AEC San Francisco Operations Office

Director, Reactor Division 
No. of

Copies

4

Argonne National Laboratory

R. A. Jaross

LMFBR Program office

N. J. Swanson

1 Atomic Power Development Assoc.

Document Librarian

$7 \quad$ Atomics International

FFTF Program Office

Liquid Metal Information Center

2 Babcock \& Wilcox Co. Atomic Energy Division

S. H. Esleeck

G. B. Garton

10 Bechtel Corporation

J. J. Teachnor, Project Administrator, FFTF

1 BNW Representative

R: M. Fleischman (ZPPR)

1 Combustion Engineering

1000 MWe Follow-On Study

W. P. Staker, Project Manager

5 General Electric Company

Advanced Products Operation

Karl Cohen

Nuclear Systems Programs

D. H. Ahmann

2 Gulf General Atomic Inc. General Atomic Division

D. Coburn

1 Idaho Nuclear Corporation

D. R. deBoisblanc 
No. of

Copies

1

Stanford University

Nuclear Division

Division of Mechanical Engrg

R. Sher

1 United Nuclear Corporation

Research and Engineering Center

R. F. DeAngelis

15 Westinghouse Electric Corporation

Atomic Power Division

Advanced Reactor Systems

J. C. R. Kel1y

ONS ITE-HANFORD

$1 \quad$ AEC Program Office-PNL

T. A. Nemzek

1 AEC Chicago Patent Group

R. K. Sharp

3 AEC RDT Site Representatives

P. G. Holsted

2 AEC Richland Operations Office

J. M. Shivley

3 Battelle Memorial Institute

1 Bechte1 Corporation

M. O. Rothwel1 (Richland)

1 Westinghouse Electric Corporation

R. Strzelecki (Richland)

117 Battelle-Northwest

W. G. Albert

S. O. Arneson

E. R. Astley

J. M. Batch

R. E. Bardsley

A. L. Bement

R. A. Bennett

C. L. Boyd

D. C. Boyd

W. L. Bunch 
Battelle-Northwest (Contd)
C. A. Burgess
A. C. Calien
J. R. Carre11
W. L. Chase
T. T. Claudson
J . C. Cochran
P. D. Cohn
D. L. Condotta
R. R. Cone
V. A. Deliso
D. R. Doman
R. V. Dulin
J. F. Erben
E. A. Evans
T. W. Evans
L. M. Finch
E. E. Garrett
F. C. Gronemeyer
J. E. Hanson
K. M. Harmon
R. A. Harvey
B. R. Hayward
R. E. Heineman
J. W. Helm
R. J. Henning
C. W. Higby
P. L. Hofmann
$\mathrm{J}$. J. Holmes
H. E. Hylbak
H. G. Johnson
E. M. Johnston
F. J. Kempf
G. A. Last
H. D. Lenkersdorfer
C. W. Lindenmeier
H. E. Little
W. W. Little
C. E. Love
B. Mann
D. Marinos
W. B. McDonald
M. A. McLaughlin
J. S. McMahon
M. H. Meuser
J. W. Mitche11
O. B. Monteith
C. A. Munro
C. R. Nash

J. A. Perry

R. E. Peterson

H. G. Powers

O. W. Priebe

W. E. Roake

R. L. Roske

D. P. Schively

W. B. Schwinberg

J. M. Seehuus

F. H. Shadel

P. F. Shaw

D. E. Simpson

C. R. F. Smith

R. J. Squires

D. D. Stepnewski

G. H. Strong

C. D. Swanson

J. C. Tverberg

J. W. Thornton

J. C. Tobin

K. G. Toyoda

M. A. Voge1

R. C. Walker

J. H. Westsik

J. F. Wett

L. A. Whinery'

T. W. Withers

M. R. Wood

W. R. Wykoff

J. M. Yatabe

FFTF File, 703 Bldg. (10)

FFTF TPO (List "T")

Lega1-- 703 B1dg

Lega1 - ROB, 221-A

Technical Information (5)

Technical Publications (2)

R. S. Hammond 